\title{
The Practice and Effect of Transformational Leadership in Achieving School Goals in the Case of Yeka Sub City Secondary School
}

\author{
Yemane Tsehaye $^{1} \quad$ Aschalew Fekadu ${ }^{2}$ \\ 1.Fellow researcher in Addis Ababa Civil service University \\ 2.GIS \& RS specialist Datum consultancy P.L.C, Addis Ababa Ethiopia
}

\begin{abstract}
This study investigates the effect of transformational leadership and its implementation of the school goals in three selected secondary schools of Yeka Sub City, Addis Ababa Ethiopia. Thus, this research was carried out using quantitative research approach with descriptive research design. Purposive sampling was used to select principals and supervisors while probability proportional sampling technique was employed for selection of teachers. Among 225 questionnaires that were distributed 205 were returned which shows $91 \%$ response rate. The data were analyzed using SPSS version 24. The results of descriptive data were presented in tables, percentages, graphs, mean and standard deviation. The overall finding of the study depicted that the 4I's components of transformational leadership practices, and the effect of transformational leadership principals on implementation of school goals were not satisfactory as teachers and supervisors responded disagreed. Primarily, the study found that the principals are not role models and charismatic to their esteemed school community, they fear decision making and not take the right risk, limitation of principals to welcome new thinking and possibilities: and secondly they couldn't clearly articulate the school vision and mission of the school for the school community, the schools have weak communication ways and systems, repetition and dropout rate of students are increasing from year to year, educational materials and equipment's were not fulfilled in the schools. Moreover, the multiple regression analysis show that $68.4 \%$ and $75.4 \%$ of the variation in the dependent variable (drop out and repetition) respectively was explained by independent variables (Individual-consideration, Idealized, Intellectual-Stimulation, inspirational-Motivational jointly). Thus the independent variables are enough for the model prediction. In addition, the ACA and sub city education leaders involve unnecessary interference is a major problem of principals and the schools. In general, there were moderately practices of transformational leadership in the schools. Based on the major findings and conclusions, the study recommended that the schools vision must be articulated by principals and the school community, the sub city \& AEB have to give on job training and follow up to implement transformational leadership practices in the secondary schools: research should be done on students repetition and drop out in those schools in relation to the principals role.

Keywords: Transformational Leadership, Independent variables, Dependent variables, Challenges, School Goals. DOI: $10.7176 / \mathrm{JEP} / 12-07-03$
\end{abstract}

Publication date:March $31^{\text {st }} 2021$

\section{Introduction}

Without education, no country can develop socially, environmentally, and economically. The assumption is that in whatever levels of development a particular nation passes, it is the true reflection of the worth of the teachers and the leaders of the school (Oloruntegbe, 2010:706). Thus, effective and efficient school leadership is the lifeblood of the teaching-learning process which takes place in the school setting to attain the school vision, farmed to produce citizens with all-around competent personality. Some researchers indicated that the expectations of the school leaders often appear to have outstripped the quality and supply of training and support (Ingvarson, 2008). Schools are an important place where students prepare them to join their future education in universities and colleges, the school leader should work hard to realize the objective through collaborative efforts of stakeholders. The high school leaders and teachers' effort must set the college-ready expectation for students that can apply knowledge in the new situation (Conley, 2007). Similarly, (Lee, 2001) stated that people are viewed as a focus for development; it plays a vital role in the development of the country because education is the source of growth of any country. This may be one of the reasons why UNESCO declared, education is a vehicle for and an indicator of development. The essential role of leadership in any organization is to successfully lead organizational activity towards some mutually accepted attainable objectives (Laka-Mathebula, 2005). Besides a lack of cooperation and support for the leaders, the school leadership role is not so easy. It exposes many types of role conflicts because of their position. They are under pressure to attain the goals of the organization from government officials, students themselves as well as the students' families, and from the teachers (Johns, Reller, \& Morphet, 1982). This study was mainly conducted to investigate the practices of transformational leadership in Yeka secondary schools. According to the researcher's observation, there has been a wide gap in the practices of transformational leadership. 


\section{Materials and Method}

Description Spatial of the study

The study was delimited to three secondary schools of the Yeka Sub-City, particularly, Edget Chora, Kara'alo, and Yeka-Abbado Secondary Schools. Yeka Sub-city has 14 administration wereda with an estimated population of 548,686, the agro-ecological condition is Weinadega and surrounded by Entetoo Mountain, Arada, Bole, Kirkos, and Oromia region.

The spatial scope is delimited to the Addis Ababa city Administration, Yeka Sub-city is approximately about $81.5 \mathrm{Km} 2$. The geographical location extends from $380,45^{\prime}, 6$ ', to 380,53 ', 45' Easting and 90, 0', 40', to 90,5 ', 0', northing Figure 1 .

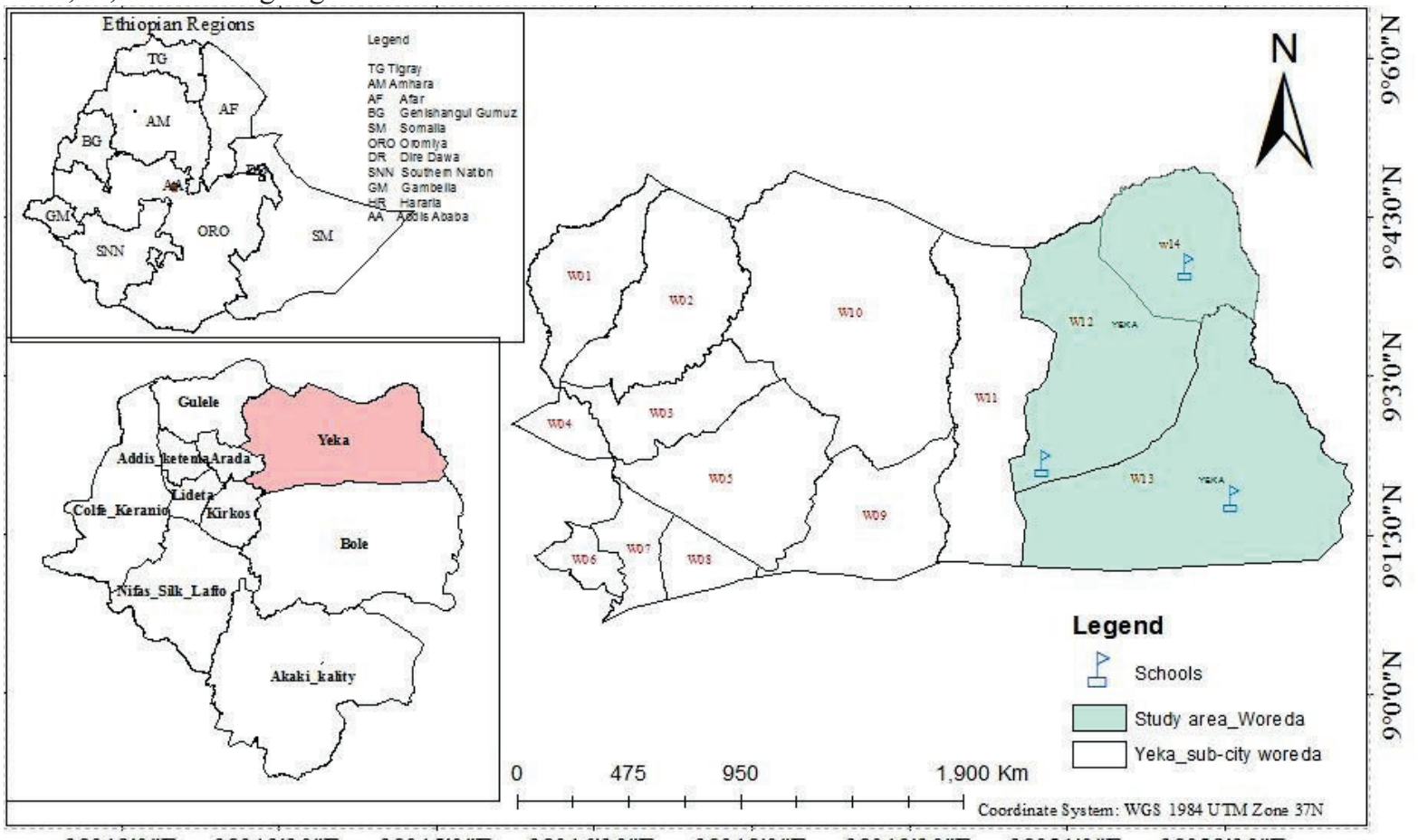

$38^{\circ} 42^{\prime} 0 " \mathrm{E} \quad 38^{\circ} 43^{\prime} 30^{\prime \prime} \mathrm{E} \quad 38^{\circ} 45^{\prime} 0^{\prime \prime} \mathrm{E} \quad 38^{\circ} 46^{\prime} 30^{\prime \prime} \mathrm{E} \quad 38^{\circ} 48^{\prime} 0 " \mathrm{E} \quad 38^{\circ} 49^{\prime} 30^{\prime \prime} \mathrm{E} \quad 38^{\circ} 51^{\prime} 00^{\prime \prime} \mathrm{E} \quad 38^{\circ} 52^{\prime} 30^{\prime \prime} \mathrm{E}$

Figure 1: Location Map of the research Area (sources:from GIS-Software by the researcher)

In Yeka sub-city, 9 governmental high schools are giving educational program from grade 9 to 12 (Etsegenet, 2019:6) from this number schools only 3 government schools were included in this study, namely Edged-Chora Secondary School, which is found in woreda 13 and it has approximately $1500 \mathrm{~m} 2 \mathrm{school}$ environment with 198 teachers, 11 department heads, 4 principals and 1 supervisor. The second one is a Kara'alo secondary school, which is found in woreda 12 and it has an approximately $2500 \mathrm{~m} 2$ school environment with 148 teachers, 11 department heads, 4 principals, and a supervisor. The third one is Abbado secondary school, which is found in wereda 14 and it has an approximately $1500 \mathrm{~m} 2$ school environment with 150 teachers, 11 department heads, 4 principals, and 1 supervisor. Therefore, the spatial scope of this research is only those three schools in the sub-city. The time coverage of the study is from the proposal preparation in July 2020 and finalized report submission at the mid of Feb 2021.

\section{Research Methodology}

The researcher used a quantitative research approach and a descriptive survey design research design. The study population was 9 government secondary schools in Yeka Sub-City which comprises 9 Principals, 27 vice principals, 12 supervisor, 1500 teachers and 99 department heads. And the total population is 1647. Three secondary schools were (Edget Chora, Kara'alo, and Abado secondary schools) were chosen for the study that has similar performance level. These schools have a total of 3 Principals, 9 Vice principals, 3 Supervisors, 496 Teachers, and 33 department heads and from these 225 respondents were taken as sample frame from the total populations. From this $3(100 \%)$ principals $9(100 \%)$ vice-principal, supervisors' $3(100 \%)$, teachers and head departments together $210(45 \%)$ were chosen in order to manage the study.

According to Kothari (2004), the research population less than 10,000, representative sample size can be determined by using the following formulae.

\section{$2[p q]^{N} / s^{2}(N-1)+z^{2}(P q)$}

$\mathrm{n}=1.96 * 1.96 * .5 * .5 * 544 / .05^{2}(544-1)+1.96 * .5 * .5$ 
$0.9604 * 544$

\section{$522.4576 / 2.3179$}

$\mathrm{n}=\mathbf{2 2 5}$

Where $\mathrm{N}=$ population size $=544$

$\mathrm{n}=$ the desired sample size

$\mathrm{z}=$ the standard normal variable at a required level of confidence $=1.96$

$\mathrm{p}=$ the estimated proportion of an attribute that is present in the population $=0.5$

$\mathrm{q}=1-\mathrm{p}=1-0.5=0.5$,

$\mathrm{e}=$ level of statistical significance of target population/desired level of precision.

Therefore, the researcher desires a $95 \%$ confidence level and $\pm 5 \%$ precision at 544 (total population of three schools); the Sample Size (n) for Precision $(\mathrm{d}=0.05)$ will be calculated as follow: Here the number of sample respondents from the total population of three secondary schools will be determined proportionally by using the following formula,

Number of sample from Edget Chora $=\mathrm{n}(\mathrm{N} 1 / \mathrm{N})=225(214 / 544)=88$ respondents, Kara'alo $=\mathrm{n}(\mathrm{N} 2 / \mathrm{N})=225$ $(164 / 544)=68$ respondents and $=\mathrm{n}(\mathrm{N} 3 / \mathrm{N})=225(166 / 544)=69$ respondents

Where $n=$ number of total sample, $\mathrm{N} 1=$ total population of Edget Chora

$\mathrm{N} 2=$ total population of Kara'alo, N3=total population of Abado

$\mathrm{N}=$ the sum of total population of all three secondary schools $=544$ and the kth constant number that allows selecting respondents systematically will determined by dividing the number of population of each school for their respective sample size. Accordingly, kth value for Edget Chora $=214 / 88=2.4$, for Kara'alo $164 / 68=2.4$ and for $A b a d o=166 / 69=2.4$ have equal chances to be participate the three schools in the study.

This study used both questionnaires and document analysis data collection tools. Questionnaires was used to collect reliable and adequate primary data from the targeted respondents. 225 respondents were selected and properly divided for the three secondary schools were being chosen to participate. 52 similar close-ended items questions were prepared for principals, vice-principals, department heads, teachers and supervision together to study the transformational leadership roles/ practices and their effect on the school goals. To strengthen the questionnaire result 3 open ended item questions were also prepared for each respondent. The questionnaire items are derived from the basic questions and it's designed to be relevant, as well as easy to respond. The questionnaires are also prepared using Likert five type rating scales, many researchers prefer to use a Likert-type scale because it's very easy to analyze statistically (Juckson, 2009, p.89). (5=Strongly Agree (SA) 4=Agree (A) $3=$ Undecided (UD) 2=Disagree (DA) 1=Strongly Disagree (SD).

\section{Demographic Condition of Respondents}

This section displays the personal information of the respondents based on their frequency distribution and the percentage analysis is given. As shown in Figure 4.1, of respondents in $64.4 \%$ were males while $35.6 \%$ were male. A large percentage $(29.8 \%)$ of the respondents were within the age of 26 to 30, whereas the smallest percentage $(6.8 \%)$ of the respondents are within the age of 14 to 25 figure 4.2 . From the total respondents, the largest percentage $(70.7 \%)$ of the respondents were degree holders, $24.4 \%$ were master degree holders, and the rest $4.9 \%$ another figure 4.3 . Also, out of the total respondents high experienced ( $>21$ years) respondents were few in numbers and covers only the least percentage $(11.2 \%)$ while the largest number of respondents with the highest percentage (27.8) have work experience between 6 to 10 years. Generally, when we look at the distribution of the respondents by their current work position the largest number of the respondents are teachers whereas the smallest number of the respondents were supervisor's figure 4.4 .

\section{Data Analysis}

\section{Practices of Transformational Leadership to Idealization Influence}

Transformational leadership, idealization influence shows charismatic elements (Howell \& Shamir, 2005) in which leaders become role models who are trusted by their followers in the working environment (Stewart, 2006). However, the obtained data in table 4.2 shows that more than half of the teachers (51\%) and supervisors $(66.7 \%)$ discomforted on the role model of their principals. On the other side, $24 \%$ of the teachers also don't decide their views blatantly. Nevertheless, the calculated mean $(\mathrm{M}=2.87, \mathrm{SD}=1.021)$ values revealed that showing a strong role model in the school was relatively practiced moderately. 
Table 4.2 Strong role model in the school

\begin{tabular}{|l|l|c|c|c|c|c|c|}
\hline \multirow{2}{*}{ Question } & \multirow{2}{*}{ Measures } & \multicolumn{5}{|c|}{ Respondents working positon } \\
\cline { 3 - 8 } & & \multicolumn{2}{|c|}{ Teachers } & \multicolumn{2}{c|}{ Supervisors } & \multicolumn{2}{c|}{ Directors } \\
\cline { 3 - 8 } & & Frequency & $\%$ & Frequency & $\%$ & Frequency & $\%$ \\
\hline \multirow{2}{*}{$\begin{array}{l}\text { strong role model } \\
\text { leads by doing rather } \\
\text { than simple by } \\
\text { telling }\end{array}$} & Agree & 46 & 24.2 & 1 & 33.3 & 10 & 77 \\
\cline { 2 - 8 } & undecided & 47 & 24.7 & - & - & 2 & 15.4 \\
\hline
\end{tabular}

In contrary to teachers and supervisors, $(77 \%)$ of the school directors agreed on the charismatic leaders and the other $15 \%$ never decided on which specification they decided. This clearly shows that even though the principals believe 'we are role models to our school communities', those three school communities are suffering from the role modeling of their principals. This means that school principals are not role models to their respected teachers, supervisors, and school communities as a whole. This lack of role modeling creates rough communication and work environment of the school that leads the school teachers and supervisors to go in the other side of its vision, mission, and ambition (The Wallace foundation WF (Edition, 2013). Besides, since principals are not role models to their esteemed teachers, teachers couldn't be role models to their students. Thus, students of those schools missed their trust in their teachers, supervisors, and principals that increase credibility and their achievement. Consequently, leaders and followers are not aligned with the school vision.

Since willingness to share risk to achieve the school goal is the key point in transformational leadership and as it is indicated in the literature review, figure 4.5 also indicated the willingness of principals towards sharing risk to achieve the school objective.

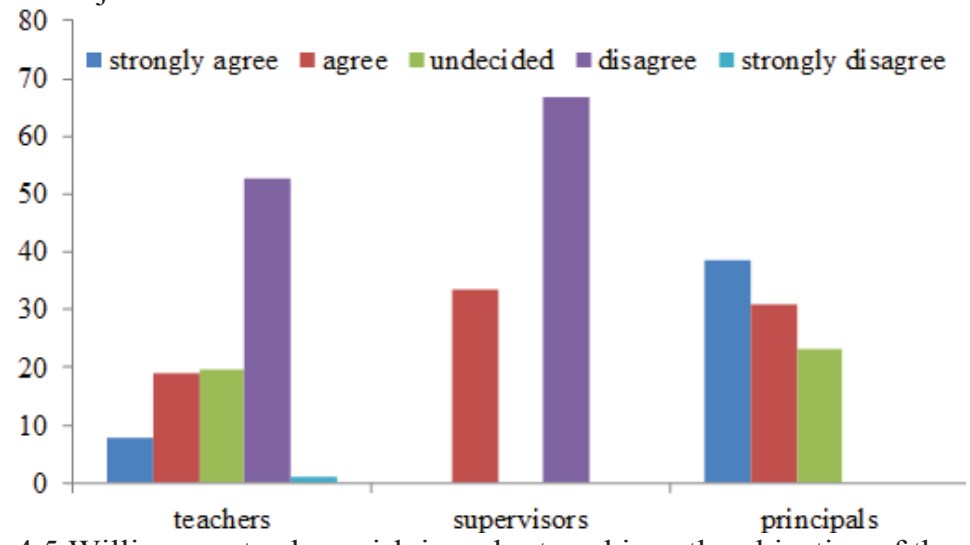

Figure 4.5 Willingness to share risk in order to achieve the objective of the school.

When we see independently, $53.7 \%$ of teachers and $66.7 \%$ of supervisors replied that school principals are not willing to take risks in their assigned schools. In other words, most of the teachers and supervisors agreed that school principals are not risk-takers of any school activities for the sake of achieving the school vision, mission, and core values. On the contrary, $69.3 \%$ of the principals replied that principals are committed to taking risks on the goodwill of the school objectives: whereas, $23 \%$ ( figure 4.5 ) of the principals are not deciding on the where of their position. This shows that most of the school principals were not very eager to scarify themselves on behalf of their assigned school. This practice of not taking risks shows how teachers, supervisors, and directors are communicating on the way to pave the way to students achievement and minimizing of students late, absents, repetition, dropout and similar problems of the school students primarily and the school community secondly. Thus, the achievement of the school objectives indicated in the school students' result in subjects (Evans-Brown, 2015) and characteristics. Therefore, based on the research, the researcher can say that principals were not willing to take risks mean teachers, supervisors, and directors didn't have good communication alignment for the great change of skill and knowledge of the school direct participant, student's achievement. Besides, the data gathered from different documents confirmed that the concepts of transformational school leadership on willingness to share risk to achieve the objective of the school were not clearly stated in any visible documents.

The literature statement stated that idealization influence is an element of transformational leadership that leaders become role models who are trusted by their school communities (Bass \& Avolio, 2004). However, the obtained data from questionnaire respondents in table 4.3 showed that only $39 \%$ of them disagreed on developing trust that can follow teachers and others while guiding the school. More than $43 \%$ of the respondents also never decided their position on the research questionnaire. This shows that trust is not developed in those three schools that lead to credible follow up of the other school communities. Similarly, 57.8\% of them also disagreed on deeply respected, admired, and trusted leaders by teachers and staff. The average mean $(\mathrm{M}=3.055)$ of these two questions showed moderately practiced trust that guides the school effectively. 
Table 4.3 Develop trust that can follow teachers and others while guiding the school

\begin{tabular}{|c|c|c|c|c|}
\hline Questions & Measure & Frequency & $\%$ & Valid percent \\
\hline \multirow{3}{*}{$\begin{array}{l}\text { Develop trust that can follow teachers and } \\
\text { others while guiding the school }\end{array}$} & Agree & 80 & 17.6 & 17.6 \\
\hline & Undecided & 89 & 43.4 & 43.4 \\
\hline & Disagree & 36 & 39 & 39 \\
\hline \multirow{3}{*}{$\begin{array}{l}\text { Deeply respected, admired and trusted by } \\
\text { teachers and staff }\end{array}$} & Agree & 57 & 27.9 & 27.9 \\
\hline & Undecided & 50 & 24.4 & 24.4 \\
\hline & Disagree & 98 & 57.8 & 57.8 \\
\hline
\end{tabular}

* The sum of agree and strongly agree is used as 'agree'; the sum of disagree and strongly disagree is used as 'disagree'.

As the review literature in chapter two noted transformational leaders show great persistence and determination in the pursuit of objectives, high standards of ethics (North house, 2007), principles, and moral conduct, sacrifice self-gain for the gain of others, consider subordinates or staff needs over their own needs and share successes and risks with subordinates, and respect and trust (Bass \& Avolio, 2004). However, table 4.4 shows $66.7 \%$ of the supervisors and $53.2 \%$ of teachers didn't agree on standards of ethical and moral conduct beyond self-interest for the goal of the school by their principals. On the other side $77 \%$ (10 out of 12) of the principals, about $33 \%$ of the supervisors, and $30.5 \%$ of teachers agreed on ethical and moral conduct beyond self-interest for the goal of the school. In connection to these, the reported average means a score of teachers, supervisors, and directors were $(\mathrm{M}=2.97, \mathrm{SD}=1.113)$. The results reveal that the principal's transformational practices in demonstrating a high standard of ethical and moral conduct beyond self-interest for the goal of the school were practiced relatively moderate.

Table 4.4 Response on demonstrates high standard of ethical and moral conduct.

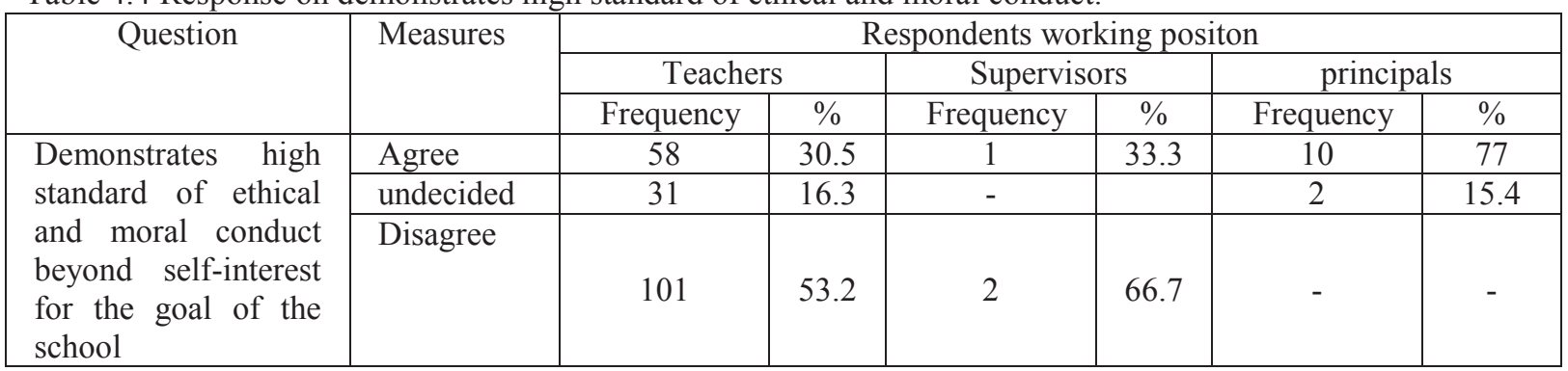

* The sum of agree and strongly agree is used as 'agree'; the sum of disagree and strongly disagree is used as 'disagree'.

This evidence indicates that principals couldn't demonstrate a high standard of ethical and moral conduct beyond self-interest for the goal of the school. Though, principals must have the ability to solve problems timely and effectively. They have to create a link between the schools and the school community. The school community must know what is going on in the school. Transformational supervisors have to facilitate and initiate school principals to prepare standards of ethical and moral conduct beyond self-interest for the goal of the school by teachers, supervisors, and principals to the school community. As the literature review indicated the practice of transformational leadership focused on building a vision and setting directions about the establishment of shared purpose as a basic stimulant for the assigned job (Howell \& Shamir, 2005). The more specific practices are building a shared vision, fostering the acceptance of group goals, and demonstrating high-performance expectations (Day et.al. 2016). The above table 4.5 shows that about $45 \%$ of the respondents agreed on providing a collective sense of mission to teachers and other school stakeholders like SPTA, students, teachers, management workers, and the school community as a whole. On the contrary, about $15 \%$ of the respondents disagree on providing a collective sense of mission to teachers and other school communities. Whereas, $39 \%$ of respondents were undecided about their view. This shows those 39\% of respondents are either lack information or they are working for the sake of salary (Miller, 2001) not for the assigned mission: Day et al. (2016) stated this as the challenge of school leaders.

Table 4.5 Provide collective sense of mission to teachers and other school stake holders

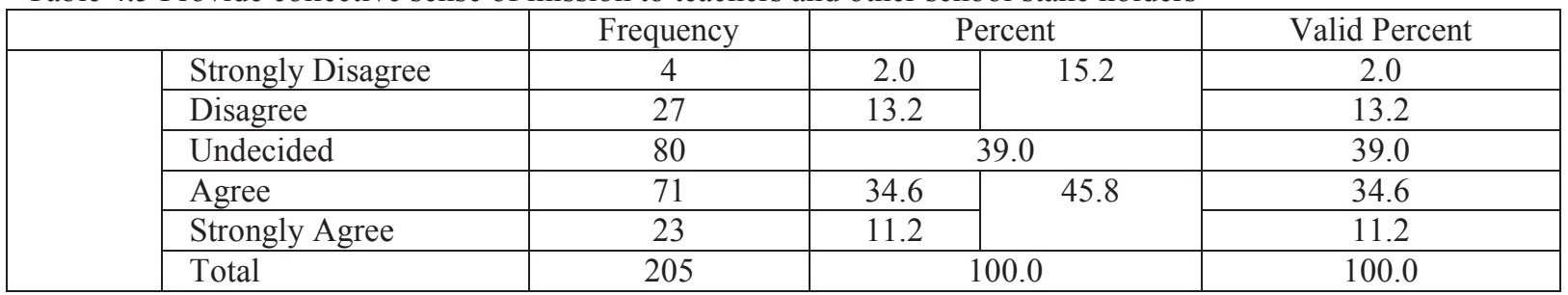

Moreover, the results in table 4.5 suggested that the principals, teachers, and supervisors' transformational 
leadership practices in fostering and providing a collective sense of mission to teachers and other school stakeholders were highly practiced $(\mathrm{M}=3.4, \mathrm{SD}=0.921)$. This clearly, shows the relationship of principals in providing a collective sense of mission to teachers and school communities (school leaders, teachers, staff members, parents, students, SPTA.) 4.3.1.6 Principals display the most important schools beliefs and value in the mission and objectives statement of the school. As it is indicated in figure 4.6 for items displaying the most important school beliefs and value in the mission and objective statement of the school, $41 \%$ of the respondents disagreed, 34\% agreed, and 24\% undecided.

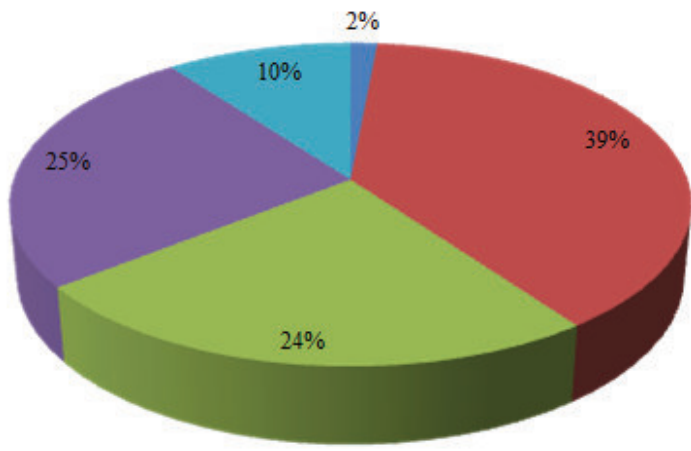

\author{
strongly agree \\ agree \\ undecided \\ disagree \\ strongly disagree
}

Figure 4.6 Schools beliefs and value in the mission and objective statement of the school

The average calculated mean score of the respondents is $(\mathrm{M}=3.04, \mathrm{SD}=1.054)$. Thus, the results suggested that teachers, supervisors, and principals' transformational leadership practice in displaying the most important schools beliefs and value in the mission and objective statement of the school in their schools were moderately practiced.

Generally, the research finding indicated that the transformational principals didn't apply different idealization elements and have limitations in assisting teachers to improve their limitations. As a result, those teachers had not got enough professional support to improve their day-to-day activities, knowledge, and skills (Soukamneuth, 2004) and (Széll, 2013). Hence, it might reduce the effectiveness of students, teacher's initiation, and achievement of the school goals (Bass \& Avolio, 2004) and (Bashir \& Afzal, 2019).

\title{
Transformational leadership practices to Inspirational Motivation
}

Since vision is very crucial for once organization's growth and development, it could be articulated by each and every organization's employees. Thus, the data below table 4.6 shows that $47.7 \%$ of the teachers, $66.7 \%$ of supervisors, and more than $69 \%$ of the principals responded $(\mathrm{M}=3.22, \mathrm{SD}=1.056)$ that they articulate a clear and attractive vision of the future about the school stakeholders. On the contrary, $34.2 \%$ of teachers and $1 \%$ of supervisors didn't agree on articulating a clear and attractive vision of the future about the school stakeholders.

Table 4.6 Articulate clear and attractive vision of future about the school to stake holders.

\begin{tabular}{|l|l|l|c|c|c|c|c|}
\hline No. & Participants & & $\begin{array}{l}\text { Strongly } \\
\text { agree }\end{array}$ & Agree & undecided & Disagree & $\begin{array}{l}\text { Strongly } \\
\text { disagree }\end{array}$ \\
\hline \multirow{2}{*}{1} & \multirow{2}{*}{ Teachers } & Freq. & 21 & 62 & 42 & 61 & 4 \\
\cline { 3 - 8 } & & $\%$ & 11.1 & 32.6 & 22.1 & 32.1 & 2.1 \\
\hline 2 & \multirow{2}{*}{ Supervisors } & Freq. & - & 2 & - & 1 & - \\
\cline { 3 - 9 } & & $\%$ & 1 & 8 & - & 33.3 & - \\
\hline \multirow{2}{*}{3} & \multirow{2}{*}{ Principals } & Freq. & 7.7 & 61.5 & 23.1 & - & - \\
\cline { 3 - 8 } & & $\%$ & & - & 3 & - & - \\
\hline
\end{tabular}

Thus, the sum of teachers, supervisors, and directors response shows that Kara'alo, Yeka Abado, and Edget Chora Secondary Schools Principals are in a good position towards exercising and articulating a clear and attractive vision of the future about the school to the school communities (school leaders, teachers, staff members, parents, students, SPTA...).

Even though, the school leadership matters to help reduce ambiguity and uncertainty in the school or society (Sashkin \& Sashkin, 2003), the cooperation of the school community has positive value for the practice of open and well-developed mutual understanding (North house, 2007) since the core mission is student's achievement. Though, leaders take constructive parts to achieve long-term goals and provide clear positive reasons for their actions, goals, and accomplishments. In this regard, table 4.7 stated $44.4 \%$ of the respondents disagreed on identifying goals areas that promote a high level of achievement for the school goals. On the contrary, $31.7 \%$ of the respondents agreed with this idea. The calculated mean value for this question is $(\mathrm{M}=2.95$, $\mathrm{SD}=1.049$ ). This shows that there was relatively moderate practice on articulating a clear and attractive vision of 
the future of the school to stakeholders. Thus, leaders have to add clarity and direction to life learning and make life more meaningful to the school communities for the sake of identifying goals and creating a mutual understanding of the school (North house, 2007).

Table 4.7 Response of teachers, supervisors and principals on inspirational motivation

\begin{tabular}{|c|c|c|c|c|c|c|c|}
\hline No & Items & Measure & Freq. & Percent & Mean & $\mathrm{N}$ & Std. d \\
\hline \multirow[t]{3}{*}{1} & \multirow{3}{*}{$\begin{array}{l}\text { Identify goals areas that promote high levels of } \\
\text { achievement for the school goals }\end{array}$} & Agree & 65 & 31.7 & \multirow[t]{3}{*}{2.95} & \multirow[t]{3}{*}{205} & \multirow[t]{3}{*}{1.049} \\
\hline & & Undecided & 49 & 23.9 & & & \\
\hline & & Disagree & 91 & 44.4 & & & \\
\hline \multirow[t]{3}{*}{2} & \multirow{3}{*}{$\begin{array}{l}\text { Promote mutual understanding and cooperation } \\
\text { among stake holders toward the common shared } \\
\text { goal of school }\end{array}$} & Agree & 75 & 36.6 & \multirow[t]{3}{*}{3.18} & \multirow[t]{3}{*}{205} & \multirow[t]{3}{*}{.949} \\
\hline & & Undecided & 72 & 35.1 & & & \\
\hline & & Disagree & 58 & 28.3 & & & \\
\hline \multirow[t]{3}{*}{3} & \multirow{3}{*}{$\begin{array}{l}\text { talk teachers enthusiastically about what need to } \\
\text { be accomplished }\end{array}$} & Agree & 94 & 45.8 & \multirow[t]{3}{*}{3.21} & \multirow[t]{3}{*}{205} & \multirow[t]{3}{*}{.995} \\
\hline & & Undecided & 48 & 23.4 & & & \\
\hline & & Disagree & 63 & 30.8 & & & \\
\hline
\end{tabular}

* The sum of agree and strongly agree is used as 'agree'; the sum of disagree and strongly disagree is used as 'disagree'

According to a review of related literature transformational leadership, as a mutual process between followers and leaders, emphasizes the needs of the followers as a central focus as well as approach goes a step further and focuses attention on the demand and growth of followers (Gibbons, 2009). This practice indicates that in transformational leadership mutual understanding is the key point for cooperation among internal and external stakeholders of the schools. The obtained data from questioner also showed that $36.6 \%$ of the respondents agreed on promoting mutual understanding and cooperation with the mean value of $(\mathrm{M}=3.18$, $\mathrm{SD}=.949)$. This clearly showed that promoting mutual understanding and cooperation among stakeholders towards the school's common goal was moderately practiced. In addition, $45.8 \%$ of the questionnaire respondents welcomed enthusiastically what needs to be accomplished in the school. This means teachers, principals, and supervisors win the successful cooperation of common goals and activities for the great success of students in those three schools.

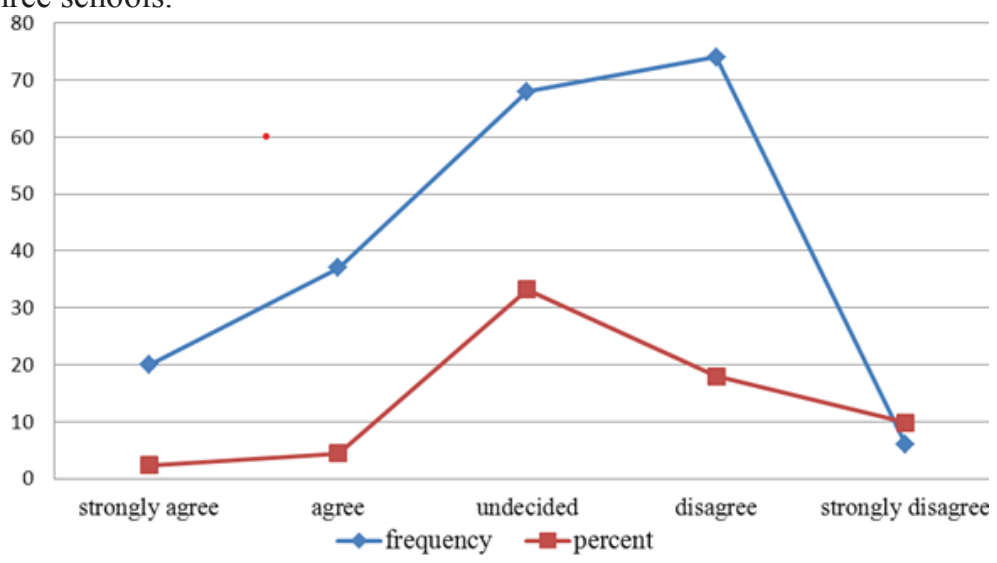

Figure 4.7 Express confidence, decisiveness and optimism that goals of the school will be achieved

According to Bush (2003), leadership is vital for clear and compelling organizational directions that contribute significantly to members' work-related motivations. The confidence of the leaders with the coordination of knowledge, skill, and decision-making paves the way to the school community's confidence towards the achievement of the school goals.

As indicated above $2.9 \%$ of the respondents strongly disagreed and $36 \%$ disagreed this means that almost $39 \%$ of the respondents disagreed. On the other side, $18 \%$ of the respondents agreed and $10 \%$ of the respondents strongly agreed on expressing confidence, decisive, and optimism that the goals of the school will be achieved. Unlike those agreed and disagreed respondents more than $33 \%$ of the respondents were undecided about their response. Those undecided respondents' response noted the ineffective communication or concern of their school culture and environment. Whereas the calculated mean value $(\mathrm{M}=2.96, \mathrm{SD}=1.026)$ indicated that there was moderately practiced of the above practices in those three schools.

One of the school leaders' practice is achieving the school vision. Thus, transformational leaders create and embrace a vision for an organization that inspires and brings the best out of people, while reflecting a belief system based on integrity and inclusiveness. However, the above figure 4.8 showed that $2.9 \%$ of the respondents strongly disagreed and $45.9 \%$ disagreed on achieving the school vision properly. The calculated mean value also stated $(M=2.87, S D=1.065)$. Likewise, $40 \%$ of the respondents disagreed and $20.9 \%$ agreed on setting an enviable example for others to follow with a mean value of $(\mathrm{M}=2.9, \mathrm{SD}=.926)$. The result shows that there was 
a relatively moderate practice of achieving the school vision properly and setting an enviable example for others to follow.

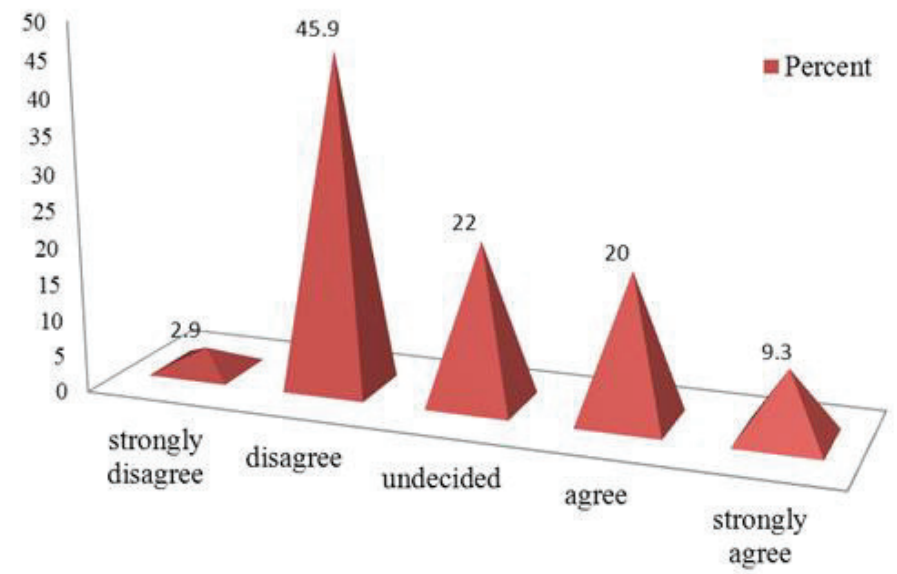

Figure 4.8. Achieve the vision of the school properly

According to the literature review, a transformational leader's concept contends that people will follow a person who inspires them; a person with vision and passion can achieve great things; and the way to get things done is by injecting enthusiasm and energy (UNESCO, 2016). Motivation, inspiration, reward, and recognition are the dominant factors in following and achieving the school vision in visionary transformational leaders. However, figure 4.9 shows that more than half percent $(52.7 \%)$ of the respondents responded that leaders couldn't motivate inspire and reward teachers to follow their vision. On the other hand, the calculated mean values of respondents $(\mathrm{M}=2.81, \mathrm{SD}=1.037)$ indicate the methods of evaluating the concepts' motivation, inspiration, and reward of the teachers to follow their vision was moderately practiced. This means that the concepts of understanding transformational school leadership motivation, inspiration, and rewards were practiced relatively moderate. Except for rare documents of rewarding students twice a year, there is no visible evidence of rewarding, motivation, and inspiration of documents in those three schools. Hence, motivation, inspiration, rewards, and recognition has a significant value for teachers and students achievement (Bass \& Avolio, 2004), school leaders should implement these key tasks in every quarter or vital years or occasions.

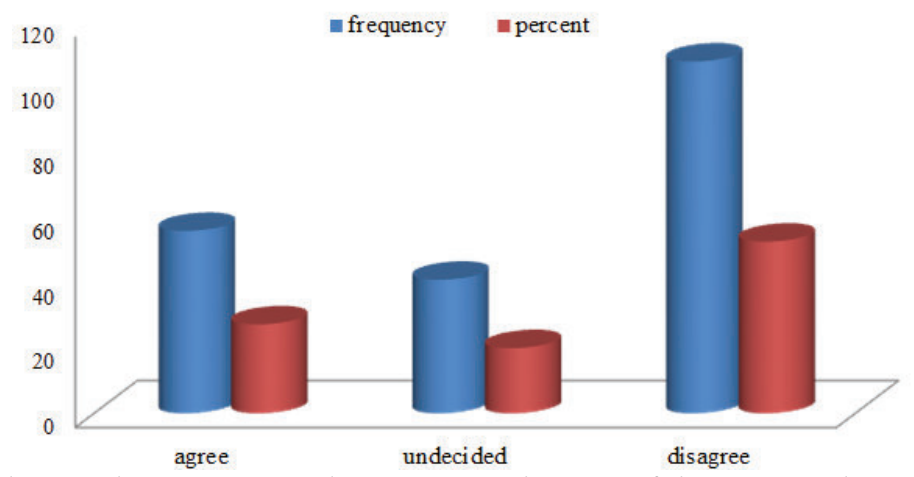

* The sum of agree and strongly agree is used as 'agree'; the sum of disagree and strongly disagree is used as 'disagree'.

Figure 4.9 Able to motivate, inspire and reward the teachers to follow their vision

In addition to the above statements, maintaining a positive team spirit among teachers is crucial for the effective transferring or sharing of ideas, knowledge, and skill among others since teachers are always students. In this regard, only $10.2 \%$ of the questionnaire respondents strongly agreed and $16.6 \%$ agreed. On the other side, $1.5 \%$ of the respondents strongly disagreed and $39 \%$ disagree. The calculated mean value $(\mathrm{M}=2.95, \mathrm{SD}=1.013)$ showed the moderate practice of transformational leaders in maintaining team spirit among teachers.

Promoting effective communication among teachers and other school communities' surges the school visibility and team spirit. The symmetric and asymmetric communication (Seitel, 2011) of the school community leads to the achievement of the school goal: effective students result. It also minimizes gossip/grapevine among the school stakeholders as a whole. In this statement, the respondent's response is 'half of full half of empty' $(50 \% / 50 \%)$. In general, the above discussion about inspirational motivation shows that the internal and external communication of those schools needs some improvement for successful and effective output. 


\section{Ttransformational leadership practices to intellectual stimulation}

The intellectually stimulating leader encourages followers to try new approaches. As it is obtained from the questionnaire result $4(2 \%)$ of the respondents strongly disagreed, 25 (17\%) disagreed, and $49(23.95 \%)$ undecided their ideas on suggesting new ways of looking at how to complete assignments of schools by their leaders: whereas $12(5.9 \%)$ strongly agreed, and $105(51 \%)$ agreed respectively with the mean value of (M=3.42, $\mathrm{SD}=.907)$.

Table 4.8 Intellectual stimulation elements (response of teachers, supervisors and principals).

\begin{tabular}{|c|c|c|c|c|c|c|c|}
\hline No & Items & Measure & Freq. & Percent & Mean & $\mathrm{N}$ & Std.d \\
\hline \multirow[t]{3}{*}{1} & \multirow{3}{*}{$\begin{array}{l}\text { Facilitate different opportunities for } \\
\text { teachers and others to develop their } \\
\text { professions }\end{array}$} & Agree & 72 & 35.1 & \multirow[t]{3}{*}{3.16} & \multirow[t]{3}{*}{205} & \multirow[t]{3}{*}{1.036} \\
\hline & & undecided & 74 & 36.1 & & & \\
\hline & & Disagree & 59 & 28.8 & & & \\
\hline \multirow[t]{3}{*}{2} & \multirow{3}{*}{$\begin{array}{l}\text { Encourage teachers to challenge the } \\
\text { status quo/to try new practices }\end{array}$} & Agree & 69 & 33.7 & \multirow[t]{3}{*}{3.06} & \multirow[t]{3}{*}{205} & \multirow[t]{3}{*}{1.005} \\
\hline & & Undecided & 70 & 34.1 & & & \\
\hline & & Disagree & 66 & 32.2 & & & \\
\hline \multirow[t]{3}{*}{3} & \multirow{3}{*}{$\begin{array}{l}\text { Seek different ideas from teachers } \\
\text { and others when solving problems }\end{array}$} & Agree & 71 & 34.6 & \multirow[t]{3}{*}{3.04} & \multirow[t]{3}{*}{205} & \multirow[t]{3}{*}{1.143} \\
\hline & & undecided & 46 & 22.4 & & & \\
\hline & & Disagree & 88 & 42.9 & & & \\
\hline \multirow[t]{3}{*}{4} & \multirow{3}{*}{$\begin{array}{l}\text { Show ability to sell the benefit of } \\
\text { new ideas }\end{array}$} & Agree & 60 & 29.3 & \multirow[t]{3}{*}{2.90} & \multirow[t]{3}{*}{205} & \multirow[t]{3}{*}{1.055} \\
\hline & & undecided & 54 & 26.3 & & & \\
\hline & & Disagree & 91 & 44.4 & & & \\
\hline \multirow[t]{3}{*}{5} & \multirow{3}{*}{$\begin{array}{l}\text { Encourage teachers to look } \\
\text { problems from different angles }\end{array}$} & Agree & 73 & 35.6 & \multirow[t]{3}{*}{3.15} & \multirow[t]{3}{*}{205} & \multirow[t]{3}{*}{1.049} \\
\hline & & undecided & 69 & 33.7 & & & \\
\hline & & Disagree & 63 & 30.7 & & & \\
\hline
\end{tabular}

* The sum of agree and strongly agree is used as 'agree'; the sum of disagree and strongly disagree is used as 'disagree'.

Thus, the value showed that there is moderate practice of transformational leadership in those three schools concerning completing assignments. As table 4.8 shows below the majority of the respondents facilitate their school teachers for different opportunities to develop their professions; similarly they also encourage them to challenge and try new practices and look at problems from different angles. On the other side, more than $42 \%$ of the respondents didn't seek different ideas from teachers and others when solving problems, correspondingly; $44.4 \%$ of them didn't show abilities to sell the benefit of new ideas. The calculated mean $(\mathrm{M}=3.062, \mathrm{SD}=1.0576)$ value of these five items below showed that there was moderately practice of transformational leadership practice of those three schools. Regarding documents, the researcher found different training documents; however, the researcher couldn't found studies and teacher encouragement documents in those three schools. In general, the study indicates that there is a moderate relationship of supervisors, teachers, and directors towards intellectual stimulations.

Encouragement is a positive stimulus for teachers to go forward to their efforts in the school activities. Regarding this most of the respondents $(35.6 \%)$ replied positive response and $33.7 \%$ undecided their ideas on encouragement of teachers and others to work their best potential by their school leaders. Unlike this, most of the respondents $77(37.5 \%)$ replied their disagreement on supporting and promoting of teachers by their principals for innovative, creative and flows free of their ideas (give) or value for learning; $49.7 \%$ and $39.5 \%$ of the respondents also noted their disagreement on the framing of problems and approaching an old situation in a new way and critical lyre-examining of assumption to questions by exploring ideas and new methods for school improvement by their school leaders respectively. This implies that even though principals believe encouragement for teachers is a positive stimulus, they are not eager and open-minded for new approaches, new thinking, and possibilities; innovations and creations of free ideas for the improvement of their schools. The researcher also never gets any visible documents on these perspectives.

This result shows that in the questions raised whether or not critically re-examines assumption to questions by exploring ideas and new methods for school improvement, encourage teachers to look at problems from different angles, seek different ideas from teachers and others when solving problems, show ability to sell the benefit of new ideas, support and frame problems and approach an old situation in a new way need serious focus and encouragement by the school principals. As Leithwood \& Jantzi (2006) stated in their review of transformational leadership research implementing the above issues had a positive relationship with the concept of school effectiveness. Because all these mentioned issues have a direct relationship with students drop out and repetition (Lucas \& Valentine, 2002).

Transformational leadership practices to individual consideration

The literature revealed that leaders build a relationship with each teacher/staff, pay attention to each individual's 
need for achievement and growth by acting as a coach or mentor, in a supportive climate to higher levels of potential (Bass \& Avolio, 2004). In this situation, individual differences in terms of needs and desires are recognized very well (Ibid). Thus, in the individual consideration part, different questionnaires have been addressed to the respondents. Regarding this, figure 4.10 tried to assess individual consideration in practices and challenges of transformational leadership in the selected secondary schools. Thus, based on the assessment more than $50 \%$ of the respondents agreed, more than $22 \%$ disagreed and $26.8 \%$ undecided their view on trying to understand the other person's viewpoints. Besides, the average mean value $(\mathrm{M}=3.39, \mathrm{SD}=.961)$ showed moderately practiced activities of transformational leadership in those three schools.

Listening and giving attention to others' viewpoints gives credit to leaders in the teaching of teachinglearning. Whether the other persons' perspective is right or wrong people need the attention of their speech delivery. Thus, transformational leaders should respect individual difference, their need and treat them equally that makes their practice visible and holistic. Regarding giving personal attention and listening carefully to others' viewpoints $43 \%$ of the respondents disproved their leader's credit. Similarly, $35 \%$ of the respondents also disagreed on giving priority to mentor and coaching to teachers in different aspects. Besides, $38 \%$ of the respondents also didn't agree on establishing trust with their immediate colleagues.

Likewise, $40 \%$ and $37 \%$ of the respondents didn't agree on reducing stress and solve problems to become effective in the teaching-learning process and focus on performance results rather than the personalities of teachers respectively. In the same ways, among all these individual consideration element questions more than $1 / 3$ of the respondents undecided about their views on the questions (see figure 4.10 for detail). Nevertheless, $34 \%$ of the respondents agreed on encouraging teachers to develop their leadership potentials. However, the calculated overall mean value $(\mathrm{M}=3.03)$ of individual consideration elements showed that those school leaders are practicing transformational leader characteristics. SPTA, teachers, and principal documents in Edget Chora and Kara'alo shows relatively progress of principals towards individual consideration elements.

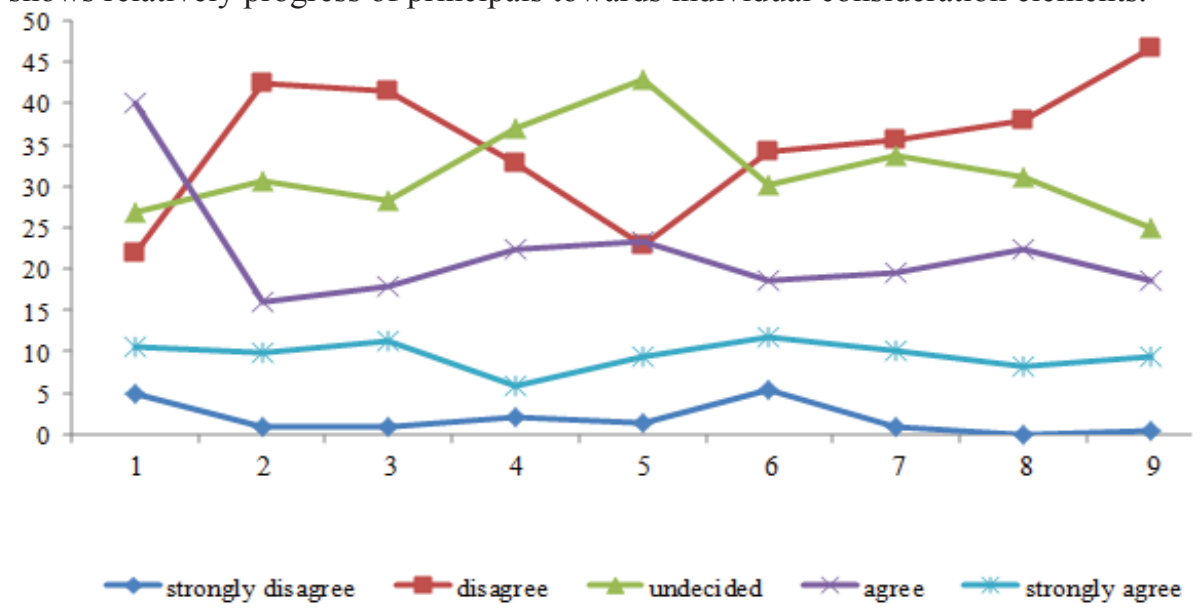

Figure 4.10 Individual consideration elements

1. Understand the other persons view points

Key:

2. Give personal attention and listen carefully to others view points

3. Respect the individual's difference, their need and treat them equally

4. Give priority to mentor or coach to teachers

5. Encourage teachers develop their own leadership potential

6. Help teachers in reducing stress and solve problems to becoming effective in their teaching learning processes

7. Focus on performance results not personalities of the teachers

8. Establish a climate of trust and fosters co-operative relationship with immediate colleagues

9. Changes his/her style and approach according to who is dealing with.

From the table, it is observed that the transformational leadership practices among the secondary school principals are at a moderate level with a mean of 3.04 and a standard deviation of 3.2. The overall mean score for all the items of transformational leadership is in the range of 2.44 to 3.67 (Creswell, 2005). The findings show that most of the respondents perceive that the practice of transformational leadership by secondary school principals in Yeka Abado, Edget Chora, and Kara'alo is moderately practiced. 
Table 4.9 Descriptive statistics of the Transformational Leadership components

\begin{tabular}{|l|c|c|c|c|}
\hline Scale & $\mathrm{N}$ & Mean & Std. deviation & Level \\
\hline Idealized influence & 205 & 3.0793 & 0.77519 & Moderate \\
\hline Inspirational motivation & 205 & 3.0112 & 0.78623 & Moderate \\
\hline Intellectual stimulation & 205 & 3.0558 & 0.81470 & Moderate \\
\hline Individualized considerations & 205 & 3.0341 & 0.78497 & Moderate \\
\hline Overall Total & 205 & 3.04 & 3.2 & \\
\hline
\end{tabular}

Finally, Leithwood (1990) states that individualized consideration, intellectual stimulation, and modeling are interpersonal practices that transformational leaders exercise and engage to shape or influence followers. These practices intend to develop a rapport and relationship with followers that will foster a culture open to change and growth of the school.

\section{Effects of Transformational Leadership in Enhancing Students Achievement or in reducing repetition}

School principals draw school goals and interpret the goals for their followers to implement based on the due dates. This school goal, most of the time, the main objective is achievement goals of students result, student's behaviors and disciplines (Dotson, 2016).

Accordingly, teachers and the other school communities develop their goals based on the school and go forward for the same destinations; departments and SPTA are the main stakeholders. Effective transformational leaders always revise their goals and let the school community to memories their objectives and visions in each and every activity. Thus, this helps them to do activities responsibly. Regarding this, the mass of the respondents $27.9 \%$ of teachers, $33.3 \%$ of supervisors, and $84.6 \%$ of the school directors replied to their agreement. This indicates that there is a relatively strong effect/tie among the school principals; supervisors and teachers in identify specific goals areas that promote high levels of achievement for students. Regarding these, the researcher couldn't get relevant documents due to transitions of school directors, supervisors, and teachers in the 2013 budget year.

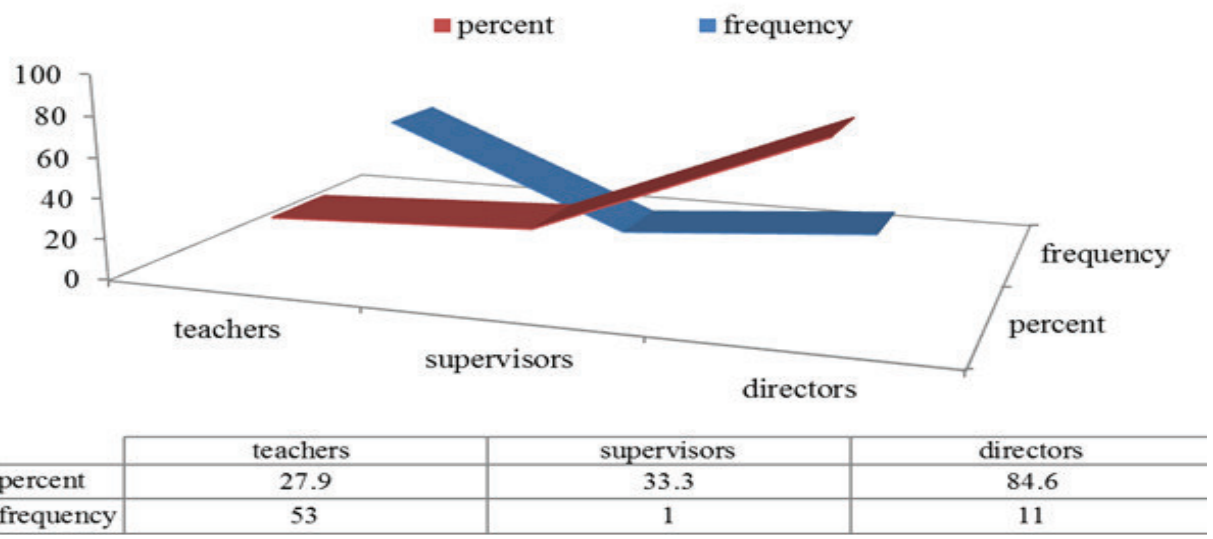

Figure 4.11 the agreement of teachers, supervisors and principals in identifying specific goals areas that promotes high levels of all students' achievements

According to the data obtained from the questionnaire respondents (teachers, supervisors, and principals), more than half of the respondents replied their agreement on encouraging teachers to try new strategies that match with their student's interests, create a safe school environment for the teaching-learning process and set the tone for respectful interaction with students by the school principals.

On the contrary, school principals have limitations on making an effort to know students achievements (by visiting the classroom), arranging to make up classes, or other means by consulting teachers in order to improve students' academic achievements (40\% disagree \& 30.8\% agree), giving more attention on formative evolution to re-enhance the students' achievement (45.4\% disagree \& $28.3 \%$ agree) and sharing the vision and inspiration of students to realize the direction of the school goal as well as their future destination (41.5\% disagree \& $33.2 \%$ agree). Even though, the calculated mean value $(\mathrm{M}=2.97)$ showed a relatively moderate practice of effective leadership practice, the effect of leadership on student's achievement with different items regarding the practices and challenges of transformational leadership in those selected secondary schools have wide difference and or gap between the teachers and principals.

\section{Effects of Transformational School Leadership in Decreasing Student's Dropout}

On understanding the consequences of student dropout, 205 questionnaires were distributed for the targets 190 teachers, 3 supervisors, and 12 directors' respondents in Yeka Sub City Kara'alo, Edget Chora, and Yeka Tafo Secondary Schools. The data were analyzed using SPSS 26 using multiple regression analysis. 


\section{Multiple regression Analysis}

Normality test

To test if residuals from the fitted model come from normally distributed data or not, we use the histogram, P-P plot of the residual, and a one-sample Kolmogorov-Smirnov test. A visual inspection of the normal probability plot suggested that the residual plots were almost close to the normal straight diagonal line, indicating that the residuals roughly followed a normal distribution figure 4.14 (a) and (b). The histogram for the standardized residuals depicted in figure 4.15 (a) and (b) also suggests the normality of the data. One-Sample Kolmogorov Smirnov test also confirms that residuals were normally distributed $(\mathrm{P}=0.348>0.05$, and $\mathrm{P}=0.144$ respectively). Therefore, no violations of the normally distributed error term assumptions.

Dependent Variable: Drop_out

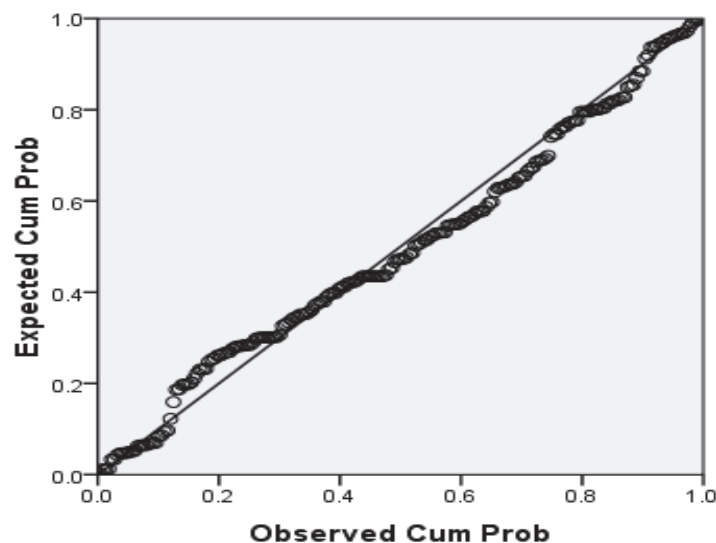

Dependent Variable: logrep

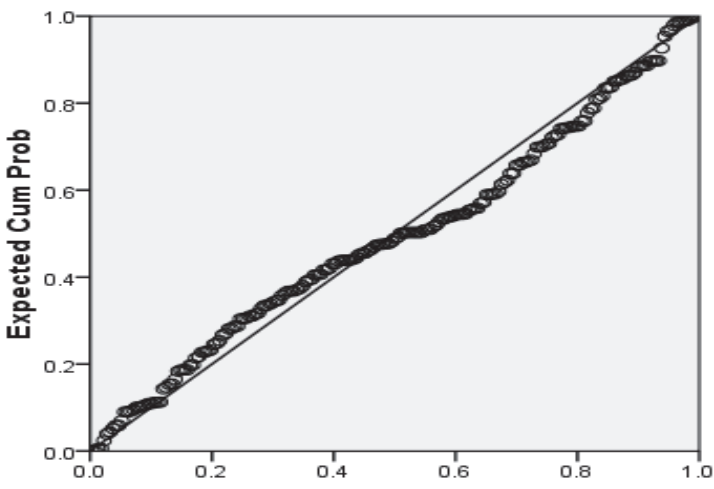

Observed Cum Prob

Figure 4.14: P-P Plot of Standardized Residuals (drop out) (a), for (repetition) (b)

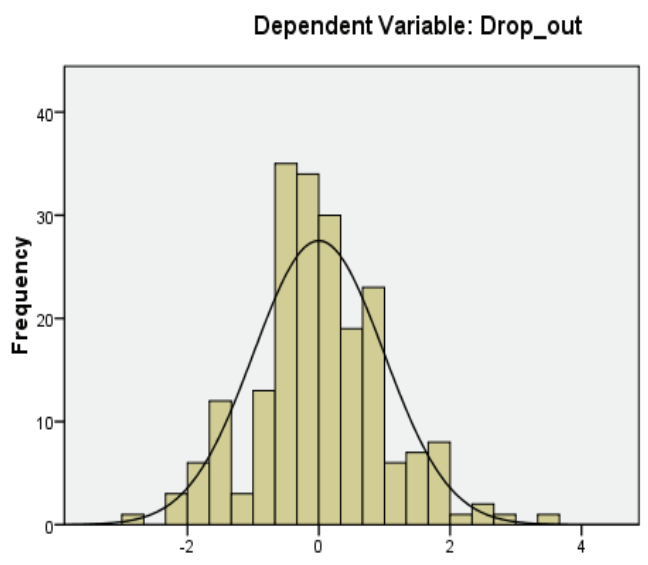

Regression Standardized Residual

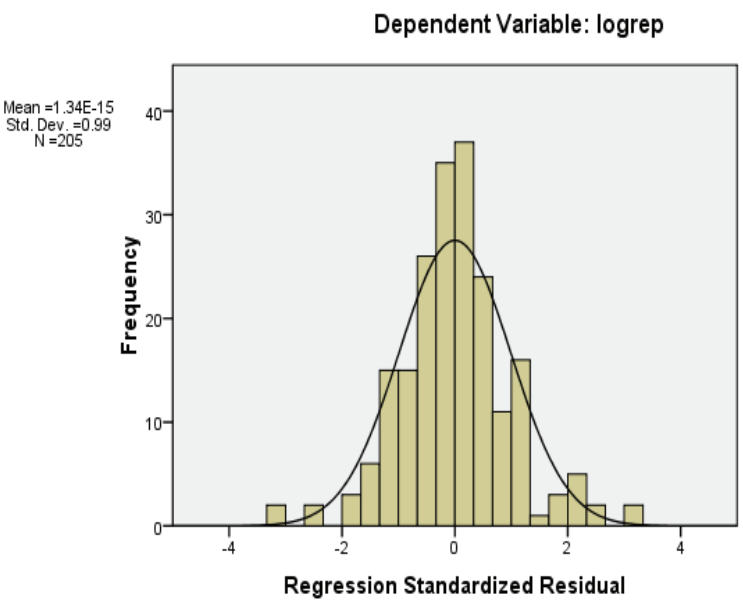

\section{Mean $=1.81 E-14$
Std. Dev $=0.99$} $N=205$

Figure 4.15: Histogram of Standardized Residuals (dropout) (a) and Residuals (repetition) (b).

\section{Test of Homoscedasticity of the Residuals}

As we can see from figure 4.16, there is no systematic pattern was seen in the plot of standardized residuals and standardized predicted values for dropout and repetition respectively, indicating that the assumption of homoscedasticity was met. The Breusch and Pagan (B-P) test also indicates that there is constant variance in the residuals for both dependent variables. 

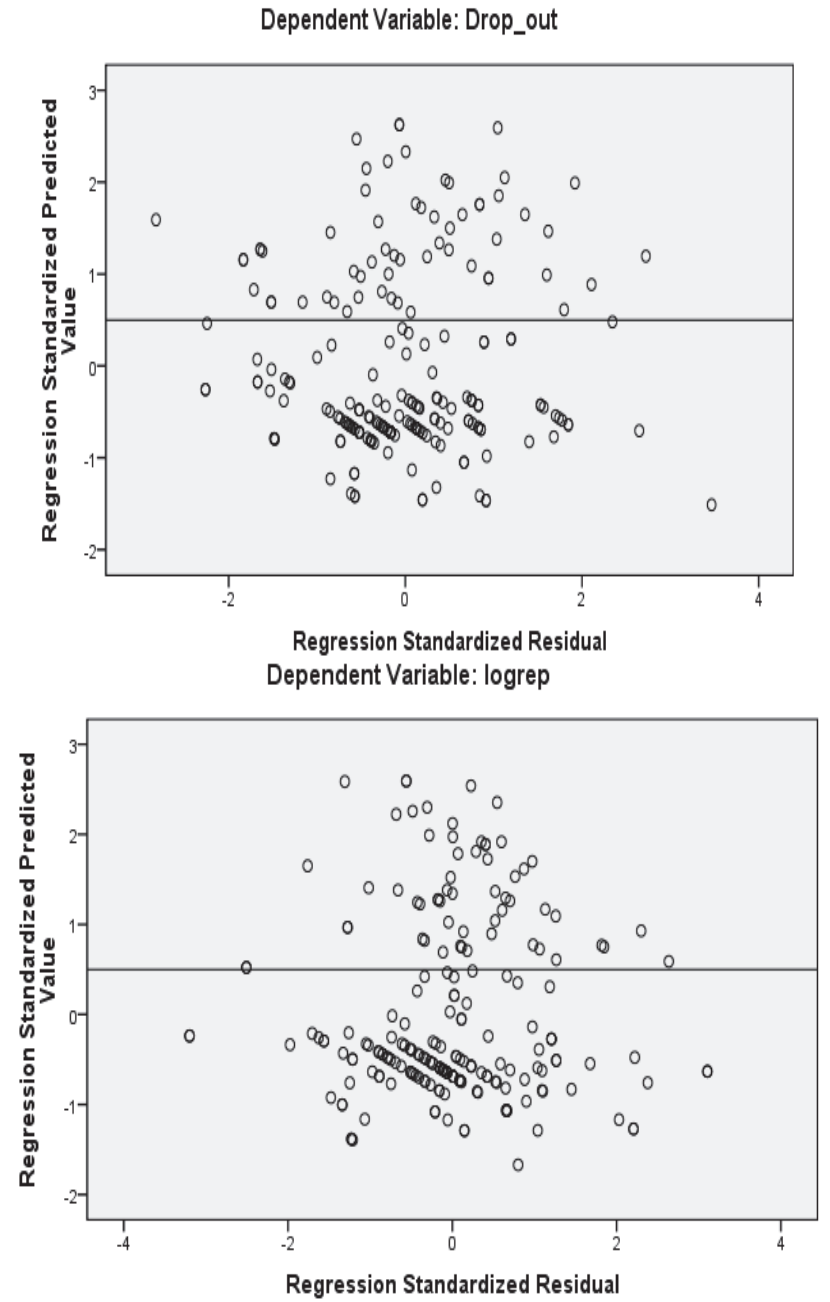

Figure 4.16: residual Scatter Plot for dropout (a), and repetition (b)

Therefore, based on diagnostics tests carried out, it can be concluded that there are no major data problems that would lead to a violation of the assumptions of multiple linear regressions. So, for further study, we can use our regression model.

The document analysis result showed that 34 male, 13 female a total of 47 students drop out in 2010; and 38 male 13 female a total 51 students repeat the same class (2010 Yeka Abado report) out of 494 total registered students. This means that 98 students dropout and repeat the same class for different reasons. In addition to this documentation in this school is very weak, the school vision, mission, and core values were not posted in the school compound in visible places that tell the school community-destination.

Similarly, in the same year 79 male, 50 female a total of 129 students repeat in 2010; 12 male and 11 female a total of 23 students drop out of the school in Kara'alo secondary school out of 1860 total registered students (2010E.C Kara'alo secondary school report). Correspondingly, in the 2011 learning year 93 male and 54 female a total of 147students repeat the same class, and 10 male and 12 female a total of 22 students drop out of the school out of 1831 total registered students (2011 Kara'alo Secondary School Report).

In the same ways, 19 male and 16 female a total of 35 students drop out of the school; 164 male and 196 female a total of 360 students repeat the same class in 2010 budget year in Edget Chora secondary school (2010 report). 2011 half-year of Edget Chora secondary school also showed 18 total dropouts and 155 repetitions of grade 9-11 (2011 half-year report). But in document analysis, there is no documented SPTA, teachers, and parents minutes concerning those students drop out and repetition. It clearly showed that those school's attention towards communication and measures, corrections towards student's achievement is ineffective. No research done is also visible in those schools. These data showed that the students drop out and repetition of schools needs due attention by all the concerned body ears and eyes.

To conclude, school leaders obviously, face daily and continuous challenges in their effort to establish and maintain a safe and orderly teaching-learning process in the school environment where teachers can teach and students can learn. One of these challenges is a student's misbehavior that are characterized by violence, absentees, less motivation, drop out, absenteeism, repetition, and others, particularly in secondary school. Thus, 
the cooperation and strategy of the school principals and school communities have an indefinite outcome for the effects of the school mission and vision statements. The value of school action research has a plus value as well. The accomplishment of the school mission and vision directly have a direct relationship for the student's achievement that where teachers, principals, and supervisors rely on.

\section{Challenges of Transformational Leadership}

The principals classified rankly the challenges according to the intensity; parents, students, teachers and teaching learning related.

Likewise, the principals listed that unnecessary interference of sub city educational bureau on academic issues and impose political duties, limitation of stake holders to understand secondary schools nature, shortages of resources (teaching materials, facilities laboratory and library), limitations of teachers to prepare plans and cooperation, low participation of parents, conflict of interest that teachers work in other private school on behalf of the public time, disciplinary problems of students were strongly stated by school principals and they also classified and ranked some challenges according their intensity as parents, students, teachers and teaching aid related.

Supervisors pointed out during their supervision time and teachers during the teaching learning process about challenges of the school leadership in leading practices and the school goal achievement. Thus, teachers and supervisors noted parents, students, teachers and teaching learning related and other challenges of the schools. In addition, supervisors and teachers stated that principals focuses on non -curricular activities, excessive meeting in the school, woreda and sub cities; give unrelated training for teachers, limitation of timely response to teachers question, limitation of understanding teachers ideas and interest, lack of fairness in serving teacher, partiality/ nepotism, lack of open and effective communication in the school and weak communication between leaders and teachers, inadequate time to mutual relationship, lack of appropriate motivation mechanism, inability to create healthy interaction with staff members, lack of permit flexibility and response to change and lack of commitment to change the school, fearing change and accountability in their duties; run way from responsibility, limitation of taking risks for the right one, limitation of role modeling to the school community, weak school management in relation to decision making, influence environmental situation for example tavern house, focused on exaggerated or falsified report in order to satisfy their sub city educational leader were mentioned dominantly. Besides, concerning the styles of the principals most of the respondents, teachers expressed their school leaders as semi autocratic/bossy way of leader ship styles(one way communication), considering themselves as boss than leaders, giving order than directions, follow un participative approach in the school activities like risk takings.

\section{Result and Discussion}

The principals are not decision-makers, they lack the confidence to make a decision; this increases the student's dropout rate and repetition alarmingly from year to year. The school principals have limitations on making an effort to know students' achievements by visiting a classroom, arranging to make up classes, or other means by consulting teachers in order to improve students' academic achievements. Motivations, inspiration, reward, and recognition have a significant value for teachers and student's achievement; however, school principals couldn't implement these key tasks in quarters, half-year, or leap years and or occasions.

Even though the factors of students drop out and repetition is students, families, schools, and communities, the area of school building contributes a lot. Surrounding the schools there are tavern houses. The school principals and school community seem couldn't give attention to these factors. The concerned government body also gives license to these bodies in few meters distance from the schools. The school principals and school community didn't do any research on the cause and effect of students drop out and repetition.

The school principals face various problems from period to period, day to day; among these excessive meetings, instability of principals in one school, interference of government bodies, limitations of resources, conflict of interest, disciplinary issues and poor communication ways, limitation of motivation, reward, and awareness, fearing change and accountability in their duties and run away responsibilities and duties were mentioned primarily.

The result of model summary showed that the explanatory power of the regression model is 0.684 and 0.751 , which shows that $68.4 \%$ and $75.4 \%$ of the variation in the dependent variable (dropout and repetition) respectively was explained by independent variables(Individual-consideration, Idealized, Intellectual-Stimulation, inspirational-Motivational jointly). In addition the from the model summary the Durbin-Watson value of the two dependent variables $d=1.840$ and $d=2.017$ respectively indicated that linear first-order autocorrelation problem. The regression coefficient indicating that there is a strong relationship between independent and dependent variables. In other words, all the independent variables can jointly affect the transformational leadership of students' achievement (repetition and drop out).

The multiple linear regression coefficient estimates show that in the final regression model all independent 
variables (factors) were statistically significant $(\mathrm{P}<0.05)$. The result of the individual test indicated that the effect of idealized is 0.144 , inspirational-Motivational is 0.187 , Intellectual Stimulation is 0.287 and Individualconsideration is 0.177 . Accordingly, the intellectual stimulation factor is a variable that has the most dominant effects on dropout (dependent variable). A unit increase in the Intellectual Stimulation factor would lead to a 0.287 increase in the effect of TF leadership in decreasing the dropout of students if all other variables were kept constant. Whereas the least effect is observed by the idealization independent variable. Similarly, the regression coefficient for repetition results shows that in the final regression model all independent variables (factors) were statistically significant $(\mathrm{P}<0.05)$, except the Idealized independent variable. According to Shumway et al., 2010 the parameters of the independent variable (in this case idealized independent variable) should be statically significantly different from zero to be included in our final model.

The result of the individual test indicated that the effect of inspirational-Motivational is 0.038 , Intellectual Stimulation is 0.041 and Individual-consideration is 0.039 .

Moreover, the individual test indicated that the most dominant variable affecting the students' repetition is a variable whose effect is significant and has the largest unstandardized $\beta$ coefficient value. Based on table-7, the Intellectual Stimulation factor is a variable that has the most dominant effects on our dependent variable. A unit increase in the Intellectual Stimulation factor would lead to a 0.041 increase in the effect of TF leadership in enhancing students' achievement (repetition) if all other variables were kept constant. Likewise, a unit increase in the Individual-consideration factor would lead to a 0.039 increase in the effect of TF leadership in enhancing students' achievement (repetition), if all other variables kept constant.

The multicollinearity result also showed that independent variables are correlated with each other i.e. correlation between variables are within the range of 0.8 to 0.9 (see in appendix Table 1 ).

\section{Conclusions}

- The three study schools are not lead by role model school principals also the principals were not risk-takers. However, teachers and supervisors take the risk for their students and teachers respectively.

- School principals didn't develop trust on teachers and others while guiding the schools, and they don't deeply respect, admired, and trusted teachers and staff members.

- The schools lack credible principals of the school community. Similarly, in the same speech teachers and supervisors, didn't agree on standards of ethical and moral conduct beyond self-interest for the goal of the school.

- Schools principals have limitations in applying transformational leadership principles in different idealization elements, on making an effort to know students achievements by visiting classroom etc., arranging to make up classes or other means by consulting teachers in order to improve students' academic achievements.

- The schools do not clearly articulate the school vision for themselves and the school communities. School principals have limitations in expressing confidence, decisiveness, and optimism that the goals of the school and couldn't motivate, inspire and reward teachers to follow their vision.

- The principals facilitate their school teachers for different opportunities to develop their professions, encourage teachers to challenge the status quo/to try new practices and look at problems from different angles. But principals were not effective in solving school challenges and problems.

- The school principals couldn't give personal attention and listens to other school communities carefully to establish mutual understanding and trust with each other.

- Yearly dropout of students is more than expected in the schools i.e. the effect of leadership on student's dropout was in question which needs radical improvement and follow up.

- Intellectual Stimulation is the most significant predictor that affects both dependent variables (dropout and repetition). Idealized have a significant effect jointly with the other independent variable on enhancing student achievement but it's individually effect is not significant.

\section{Recommendations}

- School leaders should be charismatic and strong role models, risk-taking and scarify of themselves for their given mission, vision, and ambition: student achievement. Therefore concerned government authorities should give on the job training about the issue, crisis management, and risk-taking to the school employees.

- School leaders should develop well strong organizational communication, formal \& informal communication, and other types of communication and has to communicate with their respected teachers, supervisors, and staff members as a whole.

- School principals should get on work training on how to develop confidence and decisiveness. Principals also have to give and show credits, rewards, inspiration, and motivations to their followers in the assigned school. 
- $\quad$ Policymakers and educational leaders ought to make cross-communication ways with all high schools in Addis Ababa City Administration.

- School principals should listen and give attention to the whole school community and make efforts to know students achievements, characteristics, and disciplines by visiting classrooms suddenly: should help teachers to arrange to makeup and tutorial classes.

- School principals must effectively and aggressively work on minimizing students' drop-out/repetition and the school effectiveness since it is their assignment.

- Schools should develop documentation of their efforts in the schools.

- Educational leaders, the education bureau, and Addis Ababa city administration must fulfill laboratories, libraries, and other priorities to those schools.

\section{REFERENCES}

Anderson, S. E. (2003). The school district role in educational change: A review of the literature. International Centre for Educational Change, 34(2), 25-45.

Avolio, B. J., Bass, B. M., \& Jung, D. I. (1999). Re - examining the components of transformational and transactional leadership using the Multifactor Leadership. Journal of occupational and organizational psychology, 72(4), 441-462.

Bashir, F., \& Afzal, A. (2019). Effects of Pedagogical Leadership on The Student Achievements at Secondary Level. UMT Education Review (UER), 2(2), 90-118.

Bass, B. M., \& Avolio, B. J. (2004). Multifactor Leadership Questionnaire: MLQ; manual and sampler set: Mind Garden.

Bass, B. M., \& Riggio, R. E. (2006). Transformational leadership: Psychology press.

Bush, T. (2003). Theories of educational leadership and management: Sage Publiction.

Conley, D. T. (2007). Redefining college readiness. Educational Policy Improvement Center (NJ1).

Creswell, J. W. (2005). Research Design: Qualitative, Quantitative, and Mixed Methods Approaches. (2nd. ed.). London: Sage Publication.

Day, C., Gu, Q., \& Sammons, P. (2016). The impact of leadership on student outcomes: How successful school leaders use transformational and instructional strategies to make a difference. Educational Administration Quarterly, 52(2), 221-258.

Dotson, R. (2016). Goal setting to increase student academic performance. Journal of School Administration Research and Development, 1(1), 45-46.

Edition, E. (2013). The school principal as leader: Guiding schools to better teaching and learning.

Evans-Brown, K. (2015). The link between leadership and reduced dropout rates.

Gall, M. Gall and Borg.(2003). Educational Research.. Boston: Pearson Education Inc.

Gibbons, S. (2009). Book Review: Peter G. Northouse's (2009) Introduction to Leadership: Concepts and Practices. International Journal Of Leadership Studies.

Hall, J., Johnson, S., Wysocki, A., \& Kepner, K. (2002). Transformational leadership: The transformation of managers and associates. University of Florida IFAS Extension.

Howell, J. M., \& Shamir, B. (2005). The role of followers in the charismatic leadership process: Relationships and their consequences. Academy of management review, 30(1), 96-112.

Johns, R. L., Reller, T. L., \& Morphet, E. L. (1982). Educational Organization and Administration: Concepts, Practices and Issues: Prentice-Hall.

Kothari, C. R. (2004). Research methodology: Methods and techniques: New Age International.

Laka-Mathebula, M. R. (2005). Modelling the relationship between organizational commitment, leadership style, human resources management practices and organizational trust. University of Pretoria.

Lee, J.W. (2001). Education for technology readiness: Prospects for developing countries. Journal of human development, 2(1), 115-151.

Leithwood, K., \& Jantzi, D. (2006). Transformational school leadership for large-scale reform: Effects on students, teachers, and their classroom practices. School effectiveness and school improvement, 17(2), 201 227.

Leithwood, K., Jantzi, D., \& Steinbach, R. (1999). Changing leadership for changing times: McGraw-Hill Education (UK).

Lucas, S. E., \& Valentine, J. W. (2002). Transformational Leadership: Principals, Leadership Teams, and School Culture.

Martella, R. C., Nelson, J. R., \& Marchand-Martella, N. E. (2003). Managing disruptive behaviors in the schools: A schoolwide, classroom, and individualized social learning approach: Allyn and Bacon.

Miller, D. (2001). Successful change leaders: what makes them? What do they do that is different? Journal of Change Management, 2(4), 359-368. 
Sashkin, M., \& Sashkin, M. G. (2003). Leadership that matters: The critical factors for making a difference in people's lives and organizations' success: Berrett-Koehler Publishers.

Seitel, P. F. (2011).The Practice of Public Relations: New Jersey: Pearson Education, Inc. Publishing

Soukamneuth, S. (2004). A Climate for Learning. Principal Leadership, 4(5), 14-19.

Stewart, J. (2006). Transformational leadership: An evolving concept examined through the works of Burns, Bass, Avolio, and Leithwood. Canadian Journal of Educational Administration and Policy(54).

Széll, K. (2013). Factors determining student achievement. HERJ Hungarian Educational Research Journal, 3(3), $55-66$.

Ubben, G. Hughes. LW (1997). The principal: Creative leadership for effective schools. Boston.

UNESCO, I. (2016). Basic texts of the 2003 convention for the safeguarding of the intangible cultural heritage.

Karloo Secondary school annual plan of 2011/2012. E.C and Edget Chora Secondary and preparatory school annul plan of 2012 E.C Unpublished materials, 